Relations industrielles

Industrial Relations

\title{
Information
}

\section{Note to Readers}

\section{Jean Sexton}

Volume 52, numéro 1, 1997

URI : https://id.erudit.org/iderudit/051149ar

DOI : https://doi.org/10.7202/051149ar

Aller au sommaire du numéro

Éditeur(s)

Département des relations industrielles de l'Université Laval

ISSN

0034-379X (imprimé)

1703-8138 (numérique)

Découvrir la revue

Citer ce document

Sexton, J. (1997). Information. Relations industrielles / Industrial Relations, 52(1), 3-6. https://doi.org/10.7202/051149ar

Tous droits réservés @ Département des relations industrielles de l'Université Laval, 1997
Ce document est protégé par la loi sur le droit d'auteur. L'utilisation des services d'Érudit (y compris la reproduction) est assujettie à sa politique d'utilisation que vous pouvez consulter en ligne.

https://apropos.erudit.org/fr/usagers/politique-dutilisation/ 


\section{Information}

Avec la parution de ce volume 52 de la revue Relations industrielles/ Industrial Relations, il est nécessaire de souligner trois changements que le lecteur ne manquera sûrement pas de noter.

D'abord, avec ce premier numéro de 1997, on remarquera que la couverture de la revue reproduit les logos de l'Association canadienne des relations industrielles (ACRI) et de l'Ordre professionnel des conseillers en relations industrielles du Québec (CRI). Par cette reconnaissance, nous voulons traduire concrètement les liens qui unissent ces deux organisations et la revue. En effet, depuis sa fondation en 1963, l'ACRI reconnait la revue comme son organe officiel. Ce lien de près de trente-cinq ans contribue à souder avec complicité le monde canadien des relations industrielles et la revue. Certes, la revue demeure une publication du Département des relations industrielles de l'Université Laval et a toujours conservé sa liberté éditoriale complète, mais étant la seule publication du genre dans le domaine au Canada, il est apparu utile et nécessaire à tous de tresser des liens serrés entre la revue et l'ACRI, cette dernière regroupant quelque 400 membres, surtout des universitaires, dans notre domaine.

Depuis 1983, la revue est également officiellement reconnue par les $\mathrm{CRI}$, organisation professionnelle québécoise regroupant quelque 1600 membres, surtout des praticiens patronaux, syndicaux et gouvernementaux au Québec dans le domaine des relations industrielles. Cette association entre les CRI et la revue traduit une préoccupation réciproque de rendre les travaux des chercheurs disponibles et, souhaitons-le, utiles aux praticiens dans notre domaine. De par cette collaboration, la revue est devenue pour les CRI un outil utile de formation continue. Et c'était le désir le plus cher du directeur et fondateur de la revue, Gérard Dion qui fut aussi à l'origine des CRI.

Nous avons toujours soutenu que la revue n'existait que pour ses lecteurs. Cette reconnaissance de l'ACRI et des CRI concrétise cette approche.

Ensuite, une mauvaise nouvelle qui se transforme rapidement en bonne nouvelle. Depuis 1980 (volume $35, \mathrm{n}^{\circ}$ 3) la revue publie une chronique intitulée "Changements dans la législation du travail au Canada". Chronique utile et largement appréciée d'après nos sondages, par nos lecteurs canadiens et étrangers dans les quelques 30 pays où la revue est expédiée, nous avons le regret d'annoncer que cette chronique ne sera plus publiée 
dans la revue, cette information étant désormais disponible sur le site de la Direction générale du travail de Développement des ressources humaines Canada (http ://labour.hrdc-drhc.gc.ca) de par leur décision. Nous sommes reconnaissants envers Travail Canada et Développement des ressources humaines Canada d'avoir si généreusement accepté de collaborer avec la revue au fil de tous ces ans.

Finalement, la revue veut, à partir de cette année, renforcer son ouverture internationale consacrée par le Département des relations industrielles tel qu'il appert à notre éditorial paru en 1995 dans le volume 50, numéro 1 . À partir de ce numéro, nous publierons, dans une chronique particulière intitulée Resúmenes, la traduction en espagnol de chacun des précis des articles de fond. La revue espère ainsi être plus accessible à nos collègues de cette langue et stimuler un intérêt pour utiliser la revue comme forum de diffusion des recherches en relations industrielles en espagnol.

La revue fait donc tous les efforts que lui permettent ses moyens pour s'améliorer. Les suggestions des lecteurs sont toujours grandement appréciées. Cette complicité favorisera certes une qualité croissante.

Je vous invite enfin à consulter le site Web de la revue à l'adresse suivante : http ://www.fss.ulaval.ca/rlt/rev.html.

Pour le comité de direction, JEAN SEXTON

Directeur 


\section{Note to Readers}

Readers will notice three changes in this, the first issue of volume 52 of Relations industrielles/Industrial Relations.

First, the Journal's cover bears the logos of both the Canadian Industrial Relations Association (CIRA) and the Ordre professionnel des conseillers en relations industrielles du Québec (CRI). This recognition is our way of acknowledging concretely the relationship between our journal and these two organizations. Ever since it was founded in 1963, CIRA has recognized the Journal as its official organ. This link, and continued cooperation over almost 35 years, has helped bind together the Canadian industrial relations community and the Journal. Of course, the Journal remains a publication of Laval University's Industrial Relations Department, and has always enjoyed complete editorial freedom. However, since it is the only publication of its kind in the field in Canada, it is useful to reiterate and reinforce the close ties between the Journal, CIRA and its some 400 members.

Since 1983, the Journal has also been recognized officially by CRI, Quebec's professional association of industrial relations specialists, which includes in its ranks some 1600 members from management, unions, government and academia. The association between CRI and the Journal reflects a mutual interest in making academic research results available and, we hope, of practical use to practitioners in the field. As a result of this collaboration, the Journal has become a useful educational tool for CRI. This was a wish held dear by the Journal's founding editor, Gérard Dion, who was also a founder of CRI.

We have always believed that the raison d'etre of the Journal is its readers. The appearance of the logos of CIRA and CRI on the Journal's cover is our way of giving concrete expression to this philosophy.

Next, a cloud with a silver lining. In 1980 (vol. 35, no. 3), the Journal began publishing a column entitled "Changes in Labour Legislation in Canada," which, according to our surveys, was both useful and greatly appreciated not only by our Canadian readers, but also by those in the 30 countries to which the Journal is sent. Although we regret to announce that the column will no longer be published in the Journal, this information is now available on the World Wide Web site of the Labour Directorate of Human Resources Canada (http://labour.hrdc-drhc.gc.ca). We would like to express our gratitude to Labour Canada and Human Resources Canada for having collaborated so generously with the Journal throughout all of these years. 
Finally, we are taking a further step to fulfil the mandate given to us by our department to strengthen our international orientation (see the editorial in vol. 50, no. 1). Starting with this issue, we will publish a column entitled Resúmenes, in which all of the abstracts of articles will be translated into Spanish. In this way, the Journal hopes to become more accessible to our Spanish-speaking colleagues and to stimulate an interest in using the Journal as a forum for the diffusion of industrial relations research in Spanish.

All in all, then, the Journal is making every effort within its means to improve, and readers' suggestions are always greatly appreciated. This type of cooperation will without a doubt help us to continue to improve the quality of the Journal.

In closing, we would like to invite you to visit us at our web site: http://www.fss.ulaval.ca/rlt/rev.html.

For the Executive Committee, JEAN SEXTON

Editor 